\title{
Local responsiveness strategy of foreign subsidiaries of Chinese multinationals: The impacts of relational-assets, market-seeking FDI, and host country institutional environments
}

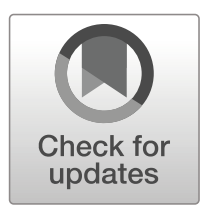

\author{
Ziyi Wei ${ }^{1} \cdot$ Quyen T. K. Nguyen ${ }^{2}$
}

Published online: 4 June 2019

(C) The Author(s) 2019

\begin{abstract}
We build upon the theoretical framework of firm-specific advantages (FSAs) and country-specific advantages (CSAs) to examine the determinants of the local responsiveness strategy of foreign subsidiaries of Chinese multinational enterprises (MNEs). Specifically, we focus on relational assets (R-assets is seen as a unique type of Chinese MNEs' FSA), the market-seeking foreign direct investment (FDI) and host country institutional environments as drivers of the local responsiveness strategy. We empirically test our hypotheses using a survey data of the foreign subsidiaries of Chinese firms together with other secondary data sources. We find that both Chinese MNEs' Rassets and the market-seeking oriented FDI are positively related to subsidiaries' local responsiveness strategy in accommodating local customer needs, government policies, market conditions, and competitive intensity. Moreover, the impact of R-assets in motivating the local responsiveness strategy is stronger in a host country with a weak and underdeveloped institutional environment. While the evidence confirms the existence of the R-assets in influencing subsidiary level strategy, it also casts doubt on such relations-based firm resources in advanced host countries with highly developed institutions.
\end{abstract}

Keywords Subsidiary strategy · Local responsiveness · Relational assets (R-assets) · Marketseeking $\cdot$ Institution-based view

Ziyi Wei

z.wei@ sheffield.ac.uk

Quyen T. K. Nguyen

t.k.q.nguyen@henley.ac.uk

1 School of East Asia Studies, University of Sheffield, 6-8 Shearwood Road, Sheffield S10 2TD, UK

2 Henley Business School, International Business and Strategy, University of Reading, Whiteknights Campus, Reading RG6 6AH, England 
Global integration and local responsiveness (I/R) framework is one of the most important theoretical models for international strategy at both corporate and subsidiary levels (Haugland, 2010; Lin \& Hsieh, 2010; Meyer \& Su, 2015). Global integration (I) is driven by economies of scale and scope focusing on cost reduction by standardising production and distribution on a worldwide basis. In contrast, local responsiveness (R) emphasizes variations of local market conditions and thus requires the subsidiary of the multinational enterprise (MNE) to adapt its operation to local circumstances (Bartlett \& Ghosbal, 1989; Prahalad \& Doz, 1987). MNEs can choose to pay more attention to one dimension than the other or to achieve both dimensions (Luo, 2001; Prahalad \& Doz, 1987; Williams, Colovic, \& Zhu, 2017).

Early studies assume that $\mathrm{I} / \mathrm{R}$ strategy is primarily determined by industrial forces so that the 'fit' between strategy and environment matters to firm performance (Johansson \& Yip, 1994; Kobrin, 1991; Porter, 1986; Taggart, 1998; Yip, 1995). However, a number of scholars argue that the degree of global integration and local responsiveness is constrained by organizational resources and capabilities (Bartlett \& Ghosbal, 1989; Luo, 2001, 2002; Rugman \& Verbeke, 1992, 2001; Tallman \& Yip, 2009). Both dimensions of I/R strategy are found to have a positive impact on firm performance (Hult, Ketchen, \& Slater, 2005; Johansson \& Yip, 1994; Meyer \& Su, 2015; Morrison \& Roth, 1992; Roth \& Morrison, 1990; Roth, David, \& Morrisson, 1991; Williams et al., 2017).

Rugman and Verbeke $(1992,2001)$ provide an interpretation of $\mathrm{I} / \mathrm{R}$ framework from the perspectives of internalization theory, especially firm-specific advantages (FSAs) and country specific advantages (CSAs) (Rugman, 1981). Rugman and Verbeke (1992) discuss the location specificity of FSAs and distinguish between non-location-bound (NLB) and location-bound (LB) FSAs. This is known as "new" internalization theory which is an extension of "classic" internalization theory (Buckley \& Casson, 1976; Rugman, 1981). Global integration is derived from NLB FSAs which are created on the basis of home CSAs, and exploited throughout MNEs' foreign subsidiaries. Local responsiveness is attributed to LB FSAs which are developed on the basis of host CSAs, thus are only functional in specific locations (Rugman \& Verbeke, 1992). As such, although global integration and local responsiveness can be inversely related, their underlying determinants are not necessarily homogeneous and should not be understood as extreme positions of a continuum (Doz \& Prahalad, 1991; Luo, 2001; Prahalad \& Doz, 1987; Tallman \& Yip, 2009).

The MNE which pursues a ‘transnational strategy' combines both global integration and local responsiveness (Bartlett \& Ghosbal, 1989; Prahalad \& Doz, 1987). Yet, the achievement of the 'transnational strategy' is rather idealistic. Even the largest MNEs need to make a choice between global integration and local responsiveness (Brock \& Hydle, 2018; Meyer \& Su, 2015; Peng, 2014; Verbeke, 2013; Williams et al., 2017).

In this paper, we argue that local responsiveness is more imperative than global integration for foreign subsidiaries of Chinese MNEs. On the one hand, NLB FSAs leading to global integration can be transferred to other locations at low cost and without substantial adaptations. All NLB FSAs developed in the home country with a transaction cost nature, such as R\&D and technology, global brands, managerial routines and capabilities, are assumed to be internationally transferable (Rugman \& Verbeke, 1992, 2001). However, the integration of these firm resources only plays a minimal role for foreign subsidiaries of Chinese MNEs due to a deficiency or a lack of 
NLB FSAs of Chinese parent firms. Instead, Chinese MNEs invest abroad to seek new strategic resources and assets through aggressive mergers and acquisitions or business partnership arrangements with foreign firms (Hennart, 2012; Peng, 2012; Ramamurti, 2009; Rugman, Nguyen, \& Wei, 2014, 2016).

On the other hand, local responsiveness is more relevant because foreign subsidiaries of Chinese MNEs suffer from the liabilities of origin in foreign markets, defined as the additional disadvantages facing these companies simply by virtue of being from emerging economies (Madhok \& Keyhani, 2012). The liabilities of origin arise from the weak and underdeveloped institutional intermediaries in China which create an unfavourable image and adverse discrimination against their foreign subsidiaries amongst host country stakeholders (Cuervo-Cazurra \& Genc, 2008; Ramachandran \& Pant, 2010).

Local responsiveness strategy means that MNEs and foreign subsidiaries need to understand local market conditions, variations in consumer tastes and demands in segmented markets, and to respond to different national standards and regulations imposed by autonomous governments and agencies (Bartlett \& Ghosbal, 1989; Prahalad \& Doz, 1987; Tallman \& Yip, 2009). The process of interaction with local actors helps subsidiaries to become locally embedded. Local embeddedness facilitates subsidiaries to develop new resources and establish local legitimacy (Birkinshaw, Hood, \& Young, 2005; Rugman \& Verbeke, 1992; Rugman, Verbeke, \& Quyen, 2011a). In other words, local responsiveness strategy is important for Chinese MNEs and their foreign subsidiaries, helping them to overcome the liabilities of origin and the related consequences of post-entry disadvantages.

However, our academic and managerial understanding on the impacts of FSAs and CSAs on local responsiveness strategy of foreign subsidiaries of Chinese MNEs is limited whereas such a body of knowledge is critical for the survival of these subsidiaries in international markets in the short term and in the long term (Brock \& Birkinshaw, 2004; Brock \& Hydle, 2018). This is a notable research gap which warrants further research.

The objective of this study is to examine the key determinants of local responsiveness strategy as perceived by senior managers of foreign subsidiaries of Chinese MNEs. We do not mean to imply that global integration should receive less academic attention. We argue that in the particular case of foreign subsidiaries of Chinese MNEs, the lack of NLB FSAs of Chinese parent firms makes subsidiaries less likely to rely on their parent-level resources in creating competitive advantages. While global integration is mainly influenced by the headquarters (HQs) for the need of internalization of existing FSAs, local responsiveness is primarily determined by foreign subsidiaries because they have a more in-depth understanding of local market conditions (Bartlett \& Ghosbal, 1989; Luo, 2001). Thus, subsidiaries are in a better position to make strategic decisions about local business directions, responding to available and accessible business opportunities and complementary resources in host countries in order to achieve performance objectives (Birkinshaw \& Pedersen, 2009; Cantwell \& Mudambi, 2005).

Specifically, we focus on FSAs and CSAs which determine local responsiveness strategy of foreign subsidiaries of Chinese MNEs. These include local relational assets (R-asset is considered as a unique type of FSA for Chinese MNEs), and host CSAs of 
market-seeking FDI and host institutional environments in which subsidiaries operate. Accordingly, we aim to address two central research questions:

1) How do these three factors influence local responsiveness strategy of foreign subsidiaries of Chinese MNEs?

2) To what extent does the development level of host country institutions moderate the impacts of local R-assets and market-seeking FDI on local responsiveness strategy?

Our paper makes three new contributions to the international business literature. First, our core contribution is to extend the theoretical work of Rugman \& Verbeke's explanation of I/R framework from "new" internalization theory perspectives. Direct empirical evidence of the IR framework in general has been very rare (Brock \& Birkinshaw, 2004; Brock \& Hydle, 2018). Previous studies typically examine industry structural forces which shape the MNE's I/R strategies, such as technology intensity, competition intensity, economies of scale, standardization of market demand, and managerial perceptions on various industrial variables (Birkinshaw, Morrison, \& Hulland, 1995; Johnson, 1995; Johansson \& Yip, 1994; Kobrin, 1991; Roth \& Morrison, 1990). A relatively small number of studies focus on the determinants of non-industrial factors. For example, Luo (2001) find that subsidiaries' established network, host country environmental complexity and cultural distance determine local responsiveness strategy of subsidiaries of Western MNEs operating in China. Hult et al. (2005) find positive impacts of market orientation and market information on local responsiveness strategy. Our study is different from prior research by theorizing and empirically testing the roles of R-assets (LB FSAs), market-seeking FDI and host country institutional environments (host CSAs) on local responsiveness strategy in a new research setting of foreign subsidiaries of Chinese MNEs.

Second, we contribute to the growing literature on the internationalization strategy of Chinese MNEs and their subsidiaries. This is a novel contribution in this research stream given that the extant knowledge on $\mathrm{I} / \mathrm{R}$ framework has been developed mainly in the context of Western MNEs operating in other advanced economies or emerging economies (e.g., Hult et al., 2005; Johansson \& Yip, 1994; Luo, 2001, 2002; Meyer \& Su, 2015; Roth et al., 1991; Williams et al., 2017). Specifically, subsidiaries of advanced economy MNEs investing abroad are able to internalize strong NLB FSAs developed in home countries (top-down knowledge transfer) (Birkinshaw et al., 2005; Birkinshaw, 2014; Rugman et al., 2011a). In contrast, foreign subsidiaries of Chinese MNEs need to search for external resources and acquire strategic assets in technology and brands in order to compete both domestically and internationally because of their parent firms' deficiencies and/or lack of internationally transferrable NLB FSAs (Hennart, 2012; Peng, 2012; Ramamurti, 2009). Their subsidiaries may transfer more knowledge to the HQs and peer subsidiaries than the stock of knowledge they receive from the HQs (Giuliani, Gorgoni, Günther, \& Rabellotti, 2014; Li, Li, \& Shapiro, 2012). Given that local responsiveness strategy enables the development of FSAs by foreign subsidiaries (Brock \& Birkinshaw, 2004; Rugman \& Verbeke, 1992, 2001), our study provides new insights into subsidiary strategies which help foreign subsidiaries of Chinese MNEs to overcome post-entry disadvantages associated with the liabilities of origin. 
Third, our study contextualizes the local responsiveness strategy of foreign subsidiaries of Chinese MNEs by examining both the direct and indirect effects of the level of host country institutional development on the relationship between local R-assets and the local responsiveness strategy. We find that these two variables have a negative synergistic effect. The finding suggests that it is critical to take into consideration the host country institutional environments when the effectiveness of R-assets of parent firms being utilized and deployed in foreign markets is evaluated. This type of LB FSA is more functional in countries with under-developed institutions than in countries with well-developed institutions. This demarcation is a new feature given that this important phenomenon has been largely under- researched in the extant literature on Chinese MNEs.

\section{Theoretical background}

\section{Local responsiveness strategy for foreign subsidiaries of Chinese MNEs}

The liabilities of origin fundamentally stem from home country institutional voids. The institutional deficiencies include weak regulatory infrastructure, rule of law and contract enforcing mechanisms, and political hazards, for example, the lack of voice and accountability, government interference and corruption (Cuervo-Cazurra \& Genc, 2008; Khanna \& Palepu, 2010). These institutional voids constrain Chinese parent firms to develop NLB FSAs in proprietary technology, brand name and management capabilities in the home country, eroding their competitiveness. In addition, the liabilities of origin create post-entry disadvantages for foreign subsidiaries of Chinese MNEs due to the negative institutional heritage and the undesirable image as perceived by various host country stakeholders (Luo \& Tung, 2007; Meyer, Ding, Li, \& Zhang, 2014; Wang, Luo, Lu, Sun, \& Maksimov, 2014). In this study, we argue that local responsiveness strategy is particularly important for foreign subsidiaries of Chinese MNEs, assisting them in overcoming the liabilities of origin in global competition (Rugman et al., 2016; Wei \& Nguyen, 2017).

First, foreign subsidiaries develop local responsiveness strategy to address the complexity and dynamism of host country conditions and business requirements associated with local customer needs, sales and distribution channels, market structures, and legal regulations (Bartlett \& Ghosbal, 1989; Prahalad \& Doz, 1987). Local responsiveness represents the 'bottom-up' knowledge because subsidiaries create new knowledge and develop innovative and learning capabilities in host countries by interacting with indigenous stakeholders. The rest of MNEs can draw upon this stock of knowledge (Brock \& Birkinshaw, 2004; Nguyen \& Rugman, 2015a). The generation of new FSAs and resources compensates for the lack of NLB FSAs of Chinese parent firms so that foreign subsidiaries can compete effectively in international markets.

Second, local responsiveness strategy requires subsidiaries to maximize delegated autonomy so that they can tap into local resources and assist them in adapting products and services to satisfy local markets and regulatory requirements (Birkinshaw, 2000; Rugman \& Verbeke, 2003). Accordingly, foreign subsidiaries undertake initiatives to build strong corporate governance and their own reputation and legitimacy in local operations (Birkinshaw, 2014; Rugman et al., 2016). Such a local embeddedness 
enables foreign subsidiaries of Chinese MNEs to disassociate themselves from their parent firms' negative institutional heritage (deriving from the home country of origin) so that they become more locally accepted (Wang et al., 2014; Wei \& Nguyen, 2017).

\section{FSAs, CSAs and foreign subsidiaries of Chinese MNEs}

We draw upon the insights of Rugman's (1981) FSAs/CSAs theoretical framework which is built upon internalization theory. The FSAs-CSAs concepts are entirely consistent with Dunning's ownership-location-internalization (OLI) paradigm, in which the CSAs can be replaced by the location advantages and the internalization (advantage) of ownership advantages is an integrated feature of FSA in practice (Eden \& Dai, 2010; Rugman, 2010; Rugman \& Verbeke, 2008).

The FSAs can be both asset-based and transaction-based (Rugman \& Verbeke, 2008). The former refers to MNEs' product or process-related proprietary assets, typically technological, manufacturing and marketing know-how. The latter refers to an organizational capability to efficiently internalise and organise assets, coordinate separate value-added activities across national boundaries, and reduce environmental and foreign risks. As such, FSAs cover a very broad set of unique firm resources and capabilities which are compatible with the resource-based view (Rugman, 2010; Rugman \& Verbeke, 2008; Rugman \& Li, 2007). The two types of FSAs are corresponding to Dunning's (1988) classification of the ownership advantages - the exclusive possession and use of certain valuable assets (Oa: asset-based ownership advantages) and the coordinating mechanism (Ot: transaction-based ownership advantages).

The CSAs or locational advantages refer to strengths and benefits specific to a country that can result from its competitive environment, labour force, geographic location, institutions, government policies, industrial clusters, and cultural factors, etc. Rugman's FSAs/CSAs analysis of firm competitiveness is for firm level strategy covering the activities of the MNE and its foreign subsidiaries in both home and host countries (Rugman, 1981, 2010; Rugman \& Verbeke, 2001, 2008).

\section{Relational-assets (R-assets) as a type of location bound (LB) FSA of Chinese MNEs}

R-assets are defined as 'the stock of a firm's willingness and capability to access, create, to shape economically, and to coordinate the resources and capabilities necessary to beneficial relationships, and to sustain and upgrade the quality of these relationships' (Dunning, 2004: 205). We define local R-assets at the firm level, because connections between individuals are often dedicated to and applied by the organization in its business operations (Luo, Shenkar, \& Nyaw, 2002; Luo, Huang, \& Wang, 2012). Dunning $(2003,2004)$ argue that R-assets constitute one type of the transaction-based FSAs as they refer to an MNE's capability of leveraging cross-border network resources and benefiting from the cumulative experience of past relationships. Indeed, the R-assets, like the transaction-based FSAs are derived from the multinationality of previous international experience (Eden \& Dai, 2010; Rugman, 2010).

Moreover, R-assets tend to be strongly contextual and they reflect cultures, ideologies and economic systems of one particular location (Dunning, 2003, 2004). R-assets of the established network of privileged access to suppliers, buyers, distributors, and 
government authorities is specific to one location and they are either home or host country-bound (Luo, 2001; Verbeke, 2013). As such, we consider R-assets as one important LB FSAs (transaction-based) and the critical determinant of local responsiveness strategy of foreign subsidiaries of Chinese MNEs.

It is well-documented in the literature that when Chinese MNEs do business in their home countries they build and exploit network relationships which help nurture cultural adaptation, mitigate institutional uncertainty and enhance strategic flexibility (Li \& Zhang, 2007; Luo et al., 2002). Accordingly, they follow business practices developed in the home country and explore international markets by building network relationships (Kotabe, Jiang, \& Murray, 2011; Wei, 2010). The importance of R-assets is particularly evident in Chinese MNEs' outward FDI because they tend to internationalize into host countries endowed with existing networks (Buckley et al., 2007; Yiu, Lau, \& Bruton, 2007). Arguably, when Chinese MNEs expand internationally, local Rassets of linkages with external parties facilitate market entry and subsequent development by accessing resources and leveraging opportunities of the business networks (Erdener \& Shapiro, 2005; Kotabe et al., 2011).

\section{Host country CSAs - Market seeking FDI}

Dunning $(1988,1998)$ identifies key location advantages of four types of international production: market seeking, efficiency seeking, natural resource seeking, and strategic asset seeking. Market seeking FDI can be explained by strong host CSAs, referring to market size and the prospects for market growth, proximity to regional markets, such as NAFTA (now known as the USMCA Agreement) and the EU, low cost of production, quality of host country infrastructure, supplier networks, customers, and government policies, etc. (Dunning \& Lundan, 2008; Rugman, 2010). This study considers marketing seeking FDI only as one CSA determinant for subsidiaries' local responsiveness strategy for three reasons.

First, unlike other FDI motives, market-seeking subsidiaries are often viewed as selfcontained production units rather than as a part of an integrated network of cross-border activities. They tend to be localized in response to customer needs, cultural diversity and government regulations (Dunning \& Lundan, 2008; Rugman, Verbeke, \& Yuan, 2011b). In order to achieve local responsiveness, subsidiary managers are often granted with autonomy in making strategic decisions for the future development of subsidiaries (Birkinshaw, 1997, 2014).

Second, Chinese MNEs' internationalization is largely motivated by market-seeking and asset-seeking FDI motives, especially in the manufacturing and service sectors (Buckley et al., 2007; Lu, Liu, \& Wang, 2011; Wang \& Shao, 2016; Wei, 2010). Chinese MNEs establishing foreign subsidiaries tend to pursue market-seeking strategies in response to intensified competition in the home country market due to trade liberalization leading to increased imports as well as increased inward FDI. Furthermore, the problems of domestic manufacturing overcapacity result in falling prices and thus force Chinese MNEs to seek new international markets to sell their products and services in response to their diminishing profits at home (Deng, 2009; Kang \& Jiang, 2012).

Third, Chinese MNEs tend to invest in host countries with large markets and growing demand to exploit economies of scale and scope (Buckley et al., 2007; 
Deng, 2009; Rugman et al., 2016). Chinese MNEs are able to develop 'good enough products' suited to emerging market conditions, which are either cheaper and more affordable, or rugged and easy for maintenance (Bhaumik \& Driffield, 2011; Ramamurti, 2009). Furthermore, Chinese MNEs have engaged aggressively in acquisitions of existing local firms in advanced economies which provide them with immediate access to local distribution channels, suppliers, customers and sales volumes (Deng, 2009; Luo \& Tung, 2007). These strategic decisions help their subsidiaries improve foreign market shares.

\section{Host country CSAs - Institutional development}

The second CSA variable examined in our study is the quality of host country institutional environment. Institutions are broadly defined as formal rules (such as political and judicial rules and laws, legal regulations and law enforcement) and informal constraints (such as cultures, norms and values) (North, 1990; Scott, 1995). Institutional advancement contributes to one important dimension of CSAs due to "rules of the game" in either home or host countries (Dunning \& Lundan, 2008; Meyer \& Nguyen, 2005; Meyer, Mudambi, \& Narula, 2011; Narula \& Santangelo, 2012; Rugman, 2010; Sun, Peng, Ren, \& Yan, 2012).

In this study, we focus on the formal institutional aspects of host CSAs only because such regulative forces have a more direct impact on market functions (Dikova \& Witteloostuijn, 2007; Lin, Peng, Yang, \& Sun, 2009). Formal institutions are found to influence the parent-level decision making, such as location of FDI and entry mode choices (Dikova \& Witteloostuijn, 2007; Kang \& Jiang, 2012; Lin et al., 2009), as well as the subsidiary-level strategies and performance (He, Zhang, \& Wang, 2015; Liu, Gao, Lu, \& Lioliou, 2016a). Foreign subsidiaries must adapt their strategy and organizational structure to respond to different institutional pressures and regulatory requirements which minimize uncertainties and transaction costs (Meyer et al., 2011; Xu \& Shenkar, 2002).

While the institution literature has extensively investigated the strategic choices and the performance of foreign subsidiaries of Western MNEs operating in China (He et al., 2015; Meyer, 2001; Sheng, Zhou, \& Li, 2011), little attention has been paid to how foreign subsidiaries of Chinese MNEs align their strategies in response to host country institutional variations when they expand internationally. Thus, in this study, we examine the relationship between host country institutional development and local responsiveness strategy of foreign subsidiaries of Chinese MNEs.

Figure 1 depicts the impact of R-assets as the NLB FSAs and host CSAs of market seeking FDI and institutional development on the local responsiveness strategy of Chinese multinational subsidiaries.

\section{Hypotheses development}

\section{Relational assets (R-assets) and local responsiveness strategy}

Local R-assets and business networks refer to local business and political ties which can be leveraged to gain competitive advantages and achieve success in local markets 


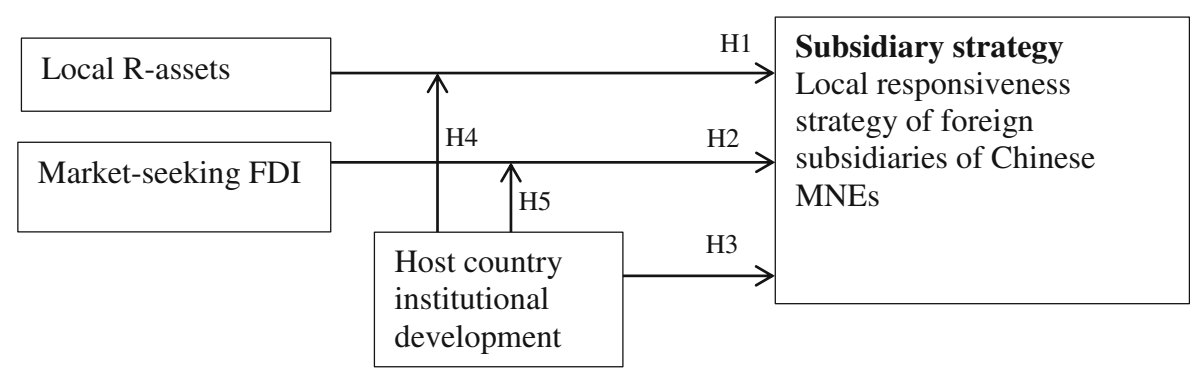

Fig. 1 Conceptual model

(Luo, 2003; Park \& Luo, 2001). As R-assets are particularly important for domestic firms and foreign investors to induce business cooperation and maintain government relationships in emerging markets, Chinese MNEs tend to explore local network relationships in their internationalization activities (Buckley et al., 2007; Kotabe et al., 2011).

In this study, we argue that R-assets facilitate foreign subsidiaries of Chinese MNEs to achieve local responsiveness strategy for three specific reasons. First, foreign subsidiaries need to develop new assets and capabilities by gaining access to complementary resources from local actors so that they can realize local responsiveness and adaptation requirements (Nguyen \& Rugman, 2015a, b; Wei \& Nguyen, 2017). However, such a combination with host CSAs is difficult since host country resources are often controlled by local firms and local governments and they are not freely accessible (Hennart, 2009, 2012; Rugman et al., 2014). It is even more challenging for foreign subsidiaries of Chinese MNEs to access local resources due to their limited international experience and local market knowledge if, as they often are, latecomers in their internationalization (Hoskisson, Wright, Filatotchev, \& Peng, 2013; Lu, Liu, Wright, \& Filatotchev, 2014; Luo \& Tung, 2007).

Local R-assets enable subsidiaries to tap into local resources in host countries through information exchange and knowledge transfer with their network partners (Park \& Luo, 2001; Zhou, Poppo, \& Yang, 2008). Business ties provide them with knowledge on products, markets, and business opportunities. Government ties grant them with access to financial resources, industrial policies, and state-owned assets (Jiang, Wang, \& Jiang, 2018; Luo, 2001, 2003; Sheng et al., 2011). As such, local Rassets heighten adaptation and localization, and improve flexibility of subsidiaries in response to changing external business environments (Luo et al., 2002; Luo, Griffith, Liu, \& Shi, 2004; Sheng et al., 2011).

Second, foreign subsidiaries of Chinese MNEs also suffer from the liabilities of origin (Ramachandran \& Pant, 2010; Wei \& Nguyen, 2017). Accordingly, their subsidiaries face greater obstacles in achieving local responsiveness strategy and acceptance compared with foreign subsidiaries of MNEs from advanced economies. Arguably, local R-assets can enhance trust since past behaviours are observable and indicative of the firm's reputation (Luo et al., 2012; Sheng et al., 2011). Local R-assets can help foreign subsidiaries of Chinese MNEs to mitigate negative image by virtue of being a part of a local network, which provides access to partners' resources and reputation in the market (Kwon, 2010). Specifically, local business ties help them to develop and introduce good quality products and services to markets, as well as induce 
customer satisfaction and loyalty (Luo et al., 2012; Peng \& Luo, 2000). Meanwhile, political ties improve political legitimacy (Rao, Chandy, \& Prabhu, 2008; Sheng et al., 2011). Therefore, local acceptance and legitimacy are important strategic resources which enable foreign subsidiaries to overcome the liabilities of origin and enhance local responsiveness strategy. Based on the above discussions, we propose that:

Hypothesis 1: Local R-assets are positively related to a local responsiveness strategy of foreign subsidiaries of Chinese MNEs.

\section{Market-seeking FDI and local responsiveness strategy}

Dunning and Lundan (2008) argue that market-seeking subsidiaries tend to be the most responsive to local needs and cultural sensitivities. In the related manner, we propose a positive relationship between market-seeking FDI and local responsiveness strategy of foreign subsidiaries of Chinese MNEs. First, market-seeking subsidiaries depend not only on the factor endowment CSAs of low cost production and innovation capacity for local manufacturing but also on marketing and information resources for local market expansion and growth (Luo, 2003; Park \& Luo, 2001; Wang, Hong, Kafouros, \& Wright, 2012). They often focus on accessing host CSAs of the output market side in terms of high demand for end products and local market knowledge, thereby fostering sales (Rugman et al., 2011a). As such, compared with other FDI motives, such as strategic asset-seeking, market-seeking subsidiaries must have an in-depth understanding of local customer needs, the degree of competition intensity, marketing and communications, sales and distribution channels (He et al., 2015).

Accordingly, market-seeking subsidiaries usually need substantial time to accumulate a well-established set of resources to develop new products or services for local customers, respond effectively to local market conditions, and develop new business opportunities (Birkinshaw, 1997; Birkinshaw et al., 2005; Birkinshaw, 2014; Rugman et al., 2014). Moreover, these downstream competences in product sales, services, and market knowledge associated with host CSAs tend to be LB FSAs which are instrumental for a local responsiveness strategy (Bouquet \& Birkinshaw, 2008; Rugman et al., 2011a).

Second, market-seeking subsidiaries are often perceived as self-contained units and they are delegated with autonomy from the HQs which enable them to develop resources to respond to local business opportunities (Birkinshaw, 1997, 2014; Dunning \& Lundan, 2008). Accordingly, the subsidiary management team is encouraged to engage in R\&D activities, product development, local employment, and operational flexibilities in order to enhance local adaptation, and increase legitimacy in the eyes of local governments and stakeholders (He et al., 2015; Luo, 2003; Tseng \& Chang, 2005).

Third, in many countries, host governments encourage export-oriented FDI by offering import tariff and value-added tax exemptions for imported raw materials and parts used in the export processing (Engman, Onodera, \& Pinali, 2007). In contrast, market-seeking subsidiaries inevitably face a greater level of pressure from host governments and local business communities because their products are manufactured and sold locally, intensifying host market competition (Luo, 2001, 2003). Therefore, subsidiaries need to employ strategic tactics geared towards unique parameters of local business norms and regulatory systems, and exert influence on institutional frameworks 
which constrain how foreign investors engage in local competition (He et al., 2015). Putting the above discussions and arguments altogether, we predict that:

Hypothesis 2: Market-seeking FDI by foreign subsidiaries of Chinese MNEs is positively related to a local responsiveness strategy.

\section{Host country institutional development and local responsiveness strategy}

In this study, we argue that local responsiveness strategy is of more importance for foreign subsidiaries of Chinese MNEs when they enter countries with advanced institutional development. There are two underlying reasons. First, the larger the institutional distance between home and host countries, the greater the pressure on subsidiaries for local responsiveness. Host country formal institutions create pressure for local isomorphism which subsidiaries must conform to adopt social and regulatory patterns and to achieve local legitimacy (Eden \& Miller, 2004; Prahalad \& Doz, 1987). Therefore, the pressure for local responsiveness is particularly pronounced in host countries with advanced institutional infrastructures, in which foreign subsidiaries of Chinese MNEs inevitably face greater liabilities of origin and discrimination by local governments, customers and business communities (Khanna \& Palepu, 2010; Madhok \& Keyhani, 2012; Ramachandran \& Pant, 2010). Accordingly, foreign subsidiaries of Chinese MNEs are prompted to disassociate themselves from the negative image of their home country. Thus, local responsiveness strategy will help them to establish a positive local reputation and legitimacy (Wei \& Nguyen, 2017). Specifically, they need to interact intensively with host-country stakeholders and take into consideration the interests of local communities in their decisions, and more importantly develop new products and services through local adaption to gain acceptance in advanced institutions (Madhok \& Keyhani, 2012; Wei \& Nguyen, 2017).

Second, well-developed institutions not only attract investment, but also enable foreign investors gain sufficient knowledge about customers, suppliers and business communities, etc. (Lu et al., 2014; Meyer, 2001; Meyer, Estrin, Bhaumik, \& Peng, 2009). Moreover, strong institutions make it less likely that local resources (such as business networks, distribution channels and labour markets, etc.) are controlled by domestic players, local state-owned enterprises (SOEs) and governments (Meyer \& Nguyen, 2005). Such supporting mechanisms for local operations not only reduce information asymmetries, but also encourage subsidiaries to adopt a local responsiveness strategy. Combining our theoretical arguments from previous studies, we predict:

Hypothesis 3: The level of host country institutional development is positively related to a local responsiveness strategy of foreign subsidiaries of Chinese MNEs.

\section{Moderating effect of host country institutional development on the relationship between R-assets and local responsiveness strategy}

In this study, we also examine the quality of host country formal institutions as a moderator influencing the relationships between local R-assets and local 
responsiveness strategy of foreign subsidiaries of Chinese MNEs. First, the utilization of R-assets is a key characteristic of doing business in many emerging economies, such as China, Russia and India, where the formal institutional framework is relatively undeveloped in terms of legal protection, market monitoring mechanisms and economic control of fragmented bureaucracy (Lin et al., 2009; Zhou et al., 2008). In such settings, firms tend to rely excessively on informal cultural-cognitive institutions of social capital to negotiate contracts and conduct business (Peng, 2003; Puffer \& McCarthy, 2011). In other words, local R-assets become more critical FSAs when dealing with business in weak institutional contexts due to a lack of formal institutional infrastructures (Xin \& Pearce, 1996; Zhang \& Keh, 2010).

Second, local R-assets facilitate subsidiaries to overcome uncertainties of pursuing a local responsiveness strategy in weak institutional environments. Local responsiveness requires the development of new knowledge or the generation of FSAs at the subsidiary level (Meyer et al., 2011; Rugman et al., 2016). However, the creation and transfer of knowledge are of particular concern in under-developed institutions because weak judicial systems and law enforcements may fail to protect intellectual property rights and innovation outputs (Dikova \& Witteloostuijn, 2007). Host country institutional voids generate hazards of expropriation and transaction uncertainties due to opaque legal systems and the weak rule of law (Buckley et al., 2007; Lu et al., 2014). Accordingly, opportunistic and unlawful behaviours (e.g., misleading advertising, piracy, contract violations and counterfeiting) become more likely (Park \& Luo, 2001). Unless there are external safeguarding mechanisms in place to impose effective supervision and punishment, local R-assets become more reliable tools to identify trustworthy partners, protect knowledge assets, and lower risks of opportunism (Kotabe et al., 2011; McMillan \& Woodruff, 1999; Xin \& Pearce, 1996).

Third, uncertainties also arise from unpredictable policy changes, corruption and bureaucratic practices in dealing with local governments in weak institutions (Ahlstrom \& Bruton, 2006; Luo et al., 2002). However, local responsiveness strategy implies that subsidiaries need to tailor business activities, products and services to local demands and government regulations (Luo, 2001; Rugman \& Verbeke, 1992, 2003). Political ties with government officials can be used not only to enforce business contracts and prevent unlawful competition, but also to obtain exclusive information about policy changes and scarce resources controlled by the government (Luo et al., 2002, 2012). Conversely, improved regulatory framework reduces the need to rely on local R-assets to mitigate business and institutional uncertainties associated with the local responsiveness strategy. Thus we propose that:

Hypothesis 4: The level of host country institutional development negatively moderates the relationship between $\mathrm{R}$-assets and the local responsiveness strategy of foreign subsidiaries of Chinese MNEs.

\section{Moderating effect of host country institutional development on the relationship between market-seeking FDI and local responsiveness strategy}

When it comes to market-seeking FDI, we argue that foreign subsidiaries of Chinese MNEs are more motivated to pursue local responsiveness strategy in institutionally 
advanced countries where they face higher liabilities of origin (as discussed previously). First, negative perceptions of the home country of origin and associated products (e.g. cheap and low quality products made in China) add extra obstacles for foreign subsidiaries of Chinese MNEs intending to increase market share in countries with advanced institutions. Customers in these countries often prefer products and services from local companies and advanced economy MNEs, which are perceived as having higher quality and safety standards (Held \& Berg, 2014; Roll, 2014). Therefore, market-seeking subsidiaries are under greater pressure to establish a positive local reputation and legitimacy through local responsiveness strategy (Wei \& Nguyen, 2017). Specifically, they need to interact intensively with host-country stakeholders and incorporate their interests through local adaptation, and develop new products and services locally to gain acceptance and increase market share in advanced institutions (Madhok \& Keyhani, 2012; Wei \& Nguyen, 2017).

Second, the liabilities of origin also reside in resource deficiencies in technology, brand and managerial capabilities at the parent level (Ramachandran \& Pant, 2010; Witt \& Lewin, 2007). As Chinese MNEs are not competitive in institutionally advanced economies, market-seeking FDI is more likely pursued in conjunction with strategic asset-seeking, in which their subsidiaries need to find ways to augment existing asset portfolios which can add value to their products and services (Dunning \& Lundan, 2008; Wang et al., 2014). Accordingly, subsidiaries need to develop new FSAs and enhance their competitiveness by taking advantage of well-established institutional endowments, learning and cooperating closely with local suppliers, customers and competitors, and educational and research institutes (Li et al., 2012; Wei \& Nguyen, 2017).

In contrast, FSAs developed by the Chinese parent firms in the home country are more relevant to host countries with under-developed formal institutional environments. In this instance, subsidiaries can achieve market-seeking and rent-generating opportunities more easily by exploiting parent-level FSAs in host countries with similar weak institutional conditions (Cuervo-Cazurra \& Genc, 2008; Cross et al., 2007; Cui \& Jiang, 2009). When foreign subsidiaries of Chinese MNEs face fewer liabilities of origin and customer demands are usually less sophisticated, local responsiveness strategy and the generation of new FSAs become less necessary for subsidiaries with market-seeking FDI in weak institutional countries (Bhaumik \& Driffield, 2011; Held \& Berg, 2014). Accordingly, we hypothesize:

Hypothesis 5: The level of host country institutional development positively moderates the relationship between market-seeking FDI and the local responsiveness of foreign subsidiaries of Chinese MNEs.

\section{Methodology}

\section{Sample and data collection by survey}

To collect our data by survey, we manually compiled a dataset of foreign subsidiaries of the top 500 Chinese manufacturing firms from information published by the China 
Enterprise Confederation and China Enterprise Directors Association in the year 2010. The headquarters of the manufacturing parent firms are located in different provinces and cities across China. The parent firms are listed on the Stock Exchanges of Shanghai, Shenzhen, Hong Kong or New York. They are required to publish company annual reports which disclose information on foreign subsidiaries (e.g., subsidiary name, parental ownership, business operations, registered assets and address). We focus on subsidiaries engaging in economic and value-adding business activities (e.g. R\&D, manufacturing, marketing, sales, distribution, etc.). The total population of our dataset includes 633 foreign subsidiaries from 144 Chinese manufacturing firms.

We used survey data for five variables in this study (see variable measurements for the detailed description). Our survey was developed and documented in English language (it will be made available upon request). To ensure the content and validity of our measurements, the questionnaire was reviewed by several senior scholars in the field of MNE subsidiary strategy and management. For pilot test purposes, we conducted eight in-depth telephone interviews with executives of the parent firms located in Zhejiang province. Based on their responses and feedback on the relevance of measurements, the design and the wording of the questions, we revised and finalised the questionnaire accordingly. The specific questions used in this study are presented in Table 1 with a detailed assessment of construct reliability and validity.

We collected data by contacting all 633 subsidiaries which are located in different countries around the world over a period of seven months between September 2011 and March 2012. We sent our questionnaire via personalised emails to either the managing director or the general manager of the target subsidiaries. We also sent our questionnaire to the 'managing director' of subsidiaries by post when we could not find information on the management team of these subsidiaries. It is well-documented in previous studies that data collection by survey is a time-consuming process and fraught with difficulties (Nguyen \& Almodóvar, 2018; Nguyen \& Rugman, 2015a, b). A total of 124 returned questionnaires were received from the foreign subsidiaries of Chinese firms. We discarded seven returned questionnaires which included incomplete information. Therefore, the final sample included 117 verified questionnaires, representing a response rate of $18.48 \%$, which is consistent with previous studies using survey data (Liu et al., 2016a; Liu, Gao, Lu, \& Lioliou, 2016b; Nguyen \& Rugman, 2015a, b) The geographical location and industrial sectors of these subsidiaries are presented in Fig. 2 and Table 2 respectively.

A two-tailed t-test comparison of location (developing versus developed host economies) and subsidiary size (registered assets) between the responding and non-responding subsidiaries shows that the two groups have similar distribution patterns in location and size. Because we sent two rounds of invitations and five rounds reminders to obtain an adequate sample size, we also compared the above characteristics between early respondents (replies after the first two rounds of invitations) and late respondents (replies after the last two rounds of reminders). There are no significant differences between these two groups, demonstrating that there is no non-response bias in the final sample.

\section{Variable measurements}

The dependent variable at the heart of our hypotheses is local responsiveness strategy, which is operationalized by a four-item scale asking subsidiary managers' perceptions 
Table 1 Construct measurements and tests of scale reliabilities

\begin{tabular}{llll}
\hline Constructs & $\begin{array}{l}\text { Measurement items of either 7-point or 5-point } \\
\text { Likert scale }\end{array}$ & $\begin{array}{l}\mathrm{C} \text { R Factor loading } \\
\text { value }\end{array}$ & \begin{tabular}{l} 
(standardized) \\
\hline
\end{tabular} \\
\hline
\end{tabular}

Local responsiveness

$($ Cronbach's alpha $=.820)$

Local R-assets (Cronbach's alpha $=.854)$ Market-seeking FDI (Cronbach's
alpha $=.804)$

\section{Strategic asset-seeking FDI}

$($ Cronbach's alpha $=.804)$

Natural resource-seeking FDI

Low cost labour-seeking FDI

Host country institutional development (Cronbach's alpha $=.967)$
After foreign entry, the subsidiary responded

actively to local environment, and adopted different products and customer service et al. for each of the following factor

local customer needs

local government policies

local market conditions

local rivalry situation

At the time of entry, to what extent did you think that the Chinese parent had established managerial or personal connections with local managers and officials at each of the following institutions?

Buyers

suppliers

distributors

competitors

officials in governments, industrial bureaus, tax bureaus, banks and commercial administration et al.

At the time of entry, to what extent was the subsidiary role related to the following statements?

seek new markets in the host country

facilitate export to the host country (e.g., collect local information, and respond to customer demands and government requirements etc.)

overcome trade barriers

provide after-sale service

At the time of entry, to what extent was the subsidiary role related to the following statements?

seek advanced technology

obtain a well-known brand

gain management know-how

At the time of entry, to what extent was the subsidiary role related to the following statements?

access to natural resources

At the time of entry, to what extent was the subsidiary role related to the following statements?

access to low-cost labour

voice and accountability

political stability 
Table 1 (continued)

\begin{tabular}{|c|c|c|c|}
\hline Constructs & $\begin{array}{l}\text { Measurement items of either 7-point or 5-point } \\
\text { Likert scale }\end{array}$ & $\begin{array}{r}\mathrm{C} \mathrm{R} \\
\text { value }\end{array}$ & $\begin{array}{l}\text { Factor loading } \\
\text { (standardized) }\end{array}$ \\
\hline & government effectiveness & & .989 \\
\hline & regulatory quality & & .972 \\
\hline & rule of law & & .979 \\
\hline & control of corruption & & .952 \\
\hline
\end{tabular}

of subsidiary responses to local customer needs, government policies, market conditions, and rivalries. This construct has been developed and used in previous studies (Luo, 2001; Meyer \& Estrin, 2014). We used a seven-point Likert scale, ranging from $1=$ not at all to $7=$ very much.

As for the independent variables, the local R-assets were built upon the construct which was developed and tested in several papers such as Jiang et al. (2018), Li, Zhou, \& Shao, (2009), Luo (2001) and Peng and Luo (2000). Specifically, subsidiary managers were asked to rate their parent firms' existing managerial or personal connections with five local stakeholders at the time of entry, including buyers, suppliers, distributors, competitors, and officials in governments and other institutions on a seven-point Likert scale, ranging from $1=$ not at all to $7=$ very much.

We developed the market-seeking FDI measurement based on the extant literature on Chinese outward FDI (Buckley et al., 2007; Buckley, Cross, Tan, Liu, \& Voss, 2008; Cross et al., 2007). The construct was captured by four items which consist of both the defensive and offensive market-seeking FDI. Specifically, subsidiary managers were asked to rate the extent to which the subsidiary was established to: 1) seek new markets in the host country; 2) facilitate export to the host country (e.g., collect local

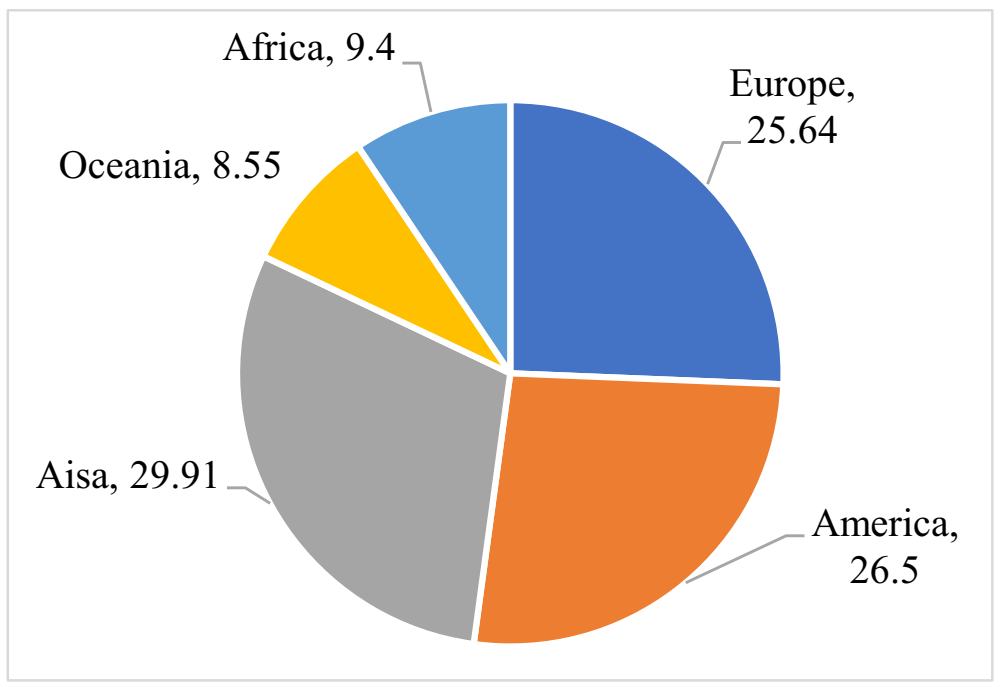

Fig. 2 Geographical distribution of the sample by percentage $(\mathrm{N}=117)$ 
Table 2 Industrial sectors of the sample $(\mathrm{N}=117)$

\begin{tabular}{lll}
\hline Industry & Count & $\%$ \\
\hline Electronic and electrical equipment and components & 25 & 21.37 \\
Machinery and computer equipment & 20 & 17.10 \\
Primary metal & 18 & 15.38 \\
Chemical and allied products & 15 & 12.82 \\
Transportation equipment & 11 & 9.40 \\
Apparel and other fabric products & 10 & 8.55 \\
Petroleum refining & 8 & 6.84 \\
Stone, clay, glass, and concrete products & 5 & 4.27 \\
Food and kindred products & 3 & 2.56 \\
Paper and allied products & 2 & 1.71 \\
All & 117 & 100 \\
\hline
\end{tabular}

information, and respond to customer demands and government requirements etc.); 3) overcome trade barriers; and 4) provide after-sale service. We used a five-point Likert scale, ranging from $1=$ not at all to $5=$ very much.

To capture the moderating variable of the level of host country institutional development, we followed previous studies (Dikova \& Witteloostuijn, 2007; Liu et al., 2016a) to use an objective measurement from the public data source of the World Bank's Governance Indicators (WGI) in the year 2010. WGI reports governance indicators for 215 economies worldwide. The six dimensions of governance are voice and accountability, political stability, government effectiveness, regulatory quality, rule of law, and corruption control. The composite measure ranges from -2.5 to 2.5 , with higher scores corresponding to higher institutional advancement.

In this study, we included a range of control variables. The ownership of the subsidiary is captured with a dummy variable with wholly-owned subsidiaries (share $\geq 95 \%$ ) coded as "1" and joint ventures as "0". Subsidiary size is measured by the logarithm of subsidiary assets in U.S. dollars. In order to address heterogeneity of Chinese parent firms (Meyer \& Estrin, 2014), we control for the marketing resources of parent firms as measured by the ratio of advertising, promotions, and marketing expenses to total sales, as well as the parent size operationalised as the logarithm of parent's total global assets in U.S. dollars. Meanwhile, we control for industry-specific effects by including nine industry dummies. The data for these control variables were sourced from Chinese parent firms' annual reports.

While we focus on market-seeking FDI, we also control for strategic assetseeking FDI by asking subsidiary managers' perceptions to rate the extent to which the subsidiary was established to: 1) seek advanced technology; 2) obtain a well-known brand; and 3) gain management know-how. We asked subsidiary managers' perceptions of natural resource-seeking FDI and low-cost labourseeking FDI by asking them to rate the extent to which the subsidiary was established to access to natural resources and low-cost labour respectively $(1=$ not at all to $5=$ very much). 


\section{Results and findings}

\section{Common method variance}

We follow the recommendations by Chang, Witteloostuijn, and Eden (2010) to address the concern of potential risks of common method variance as the dependent and independent variables were generated through a questionnaire survey. First, in our empirical analysis, the level of host country institutional development as the focal explanatory variable is taken from the archival source (public data source), thus reducing the likelihood of having the common method variance. Second, testing the moderating effect or the complex relationships between the dependent and independent variables are not part of the respondents' theory-in-use (Chang et al., 2010). Third, we used different scale types, including 1-to-7 Likert scale and 1-to-5 Likert scale in the questionnaire which reduce the likelihood of common method variance. Fourth, we conduct a Harman's single-factor test and find that the single factor model demonstrated a poor fit of the data with the largest factor explaining only $24.358 \%$ of the total variance in the analysis. Thus, common method bias is not a major threat to the subsequent hypotheses testing.

\section{Construct reliability and validity testing}

We evaluate the construct composite (CR) reliability, convergent and discriminant validity. Table 1 presents the five-factor confirmatory analysis (CFA) results, providing a good overall fit of the data with all indicators meeting the respective criteria: $X^{2}(199)$ $=211.325 ; \mathrm{RMSEA}=.023 ; \mathrm{CFI}=.993 ;(\mathrm{N}) \mathrm{NFI} / \mathrm{TLI}=.992 ; \mathrm{SRMR}=.054$. More specifically, all measures show a CR value in excess of the recommended threshold value of .70 (Hair, Black, Babin, \& Anderson, 2010). Meanwhile, all individual items load strongly, which are higher than the recommended value of .5 and they are statistically significant (Fornell \& Larcker, 1981; Hair et al., 2010). Hence, the results show good convergent validity of construct indicators. The average variance extracted (AVE) and the square of the correlation among pairs of constructs are presented in Table 3. The AVE value for each construct is higher than .50, and is larger than the squared correlation coefficients between constructs. Therefore, the measurement scales used in this study are reliable and valid (Fornell \& Larcker, 1981; Hair et al., 2010).

\section{Hypotheses testing}

Table 4 shows the descriptive statistics, correlations and variance inflation factors (VIF). All correlations are fairly low, except for the correlation between low-cost labour-seeking FDI and host country institutional development (-.625). However, the VIF of all variables are well below 10, the acceptable cut-off point (Hair et al., 2010), and the mean VIF is only 1.56. Thus, multicollinearity is not a concern.

We test our hypotheses using ordinary least square (OLS) estimates. We first test all control variables in Model 1 before including independent variables - local R-assets, market-seeking FDI, and host country institutional development in Model 2. We then add the moderating effects in Model 3. As shown in Model 1 in Table 5, two of the control variables are statistically significant. Specifically, the wholly owned subsidiary 
Table 3 Convergent and discriminant validity assessment

\begin{tabular}{|c|c|c|c|c|c|}
\hline Constructs & $\begin{array}{l}\text { Local } \\
\text { responsiveness }\end{array}$ & $\begin{array}{l}\text { Local } \\
\text { R-assets }\end{array}$ & $\begin{array}{l}\text { Market-seeking } \\
\text { FDI }\end{array}$ & $\begin{array}{l}\text { Strategic } \\
\text { asset-seeking } \\
\text { FDI }\end{array}$ & $\begin{array}{l}\text { Host country } \\
\text { institutional } \\
\text { development }\end{array}$ \\
\hline Local responsiveness & .539 & & & & \\
\hline Local R-assets & .036 & .546 & & & \\
\hline Market-seeking FDI & .001 & .007 & .511 & & \\
\hline Strategic asset-seeking FDI & .000 & .000 & .009 & .582 & \\
\hline $\begin{array}{l}\text { Host country institutional } \\
\text { development }\end{array}$ & .013 & .009 & .000 & .077 & .841 \\
\hline
\end{tabular}

AVE value for each construct is in italic

is negatively related to the local responsiveness strategy of foreign subsidiaries of Chinese MNEs, while the size of the subsidiary is positively related to the local responsiveness strategy.

We also find that there is no significant relationship between strategic asset-seeking FDI and local responsiveness strategy. It may be explained by the fact that Chinese MNEs go abroad with objectives to acquire strategic assets which can be brought back to China for exploitation as a response to increasing domestic competition (Cui, Meyer, \& Hu, 2014; Meyer, 2015; Ramamurti, 2012). Cui et al., (2014) argue that achieving local responsiveness occurs only in market-seeking FDI of Chinese MNEs, while strategic asset-seeking FDI focuses on identifying, acquiring and reverse-transferring intangible resources back to home country. For example, Geely's acquisition of Volvo and British Manganese Bronze is used to strengthen its position in China (Meyer, 2015). As such, it is less important for strategic asset-seeking subsidiaries of Chinese MNEs to develop host market based capabilities and response actively to customer demands in order to explore and maintain local market share.

In model 2 , the results $(p<.05)$ support Hypothesis 1 , which predicts that local Rassets are positively related to the local responsiveness strategy of foreign subsidiaries of Chinese MNEs. The results show that for every $1 \%$ increase in R-assets (holding other variables constant), the local responsiveness strategy increases by $16.7 \%$ on average. Our finding shows that R-assets are important resources upon which foreign subsidiaries can depend in gaining access to local complementary assets in host countries and in mitigating negative image associated with the liabilities of origin, and therefore facilitate foreign subsidiaries of Chinese firms to pursue the local responsiveness strategy.

Hypothesis 2 which predicts a positive relationship between market-seeking FDI and the local responsiveness strategy of foreign subsidiaries of Chinese MNEs is also supported $(p<.01)$. The results in model 2 show that for every $1 \%$ increase in marketseeking orientated FDI (holding other variables constant), the local responsiveness strategy increases by $34.4 \%$ on average. The relationship is statistically significant and the sign is positive, as predicted in hypothesis 2 . In other words, the greater the local market-seeking FDI of the subsidiary, the greater the local responsive strategy will be.

However, Hypothesis 3 is not supported as we find no statistically significant evidence that host country institutional advancement is a critical factor for the local 


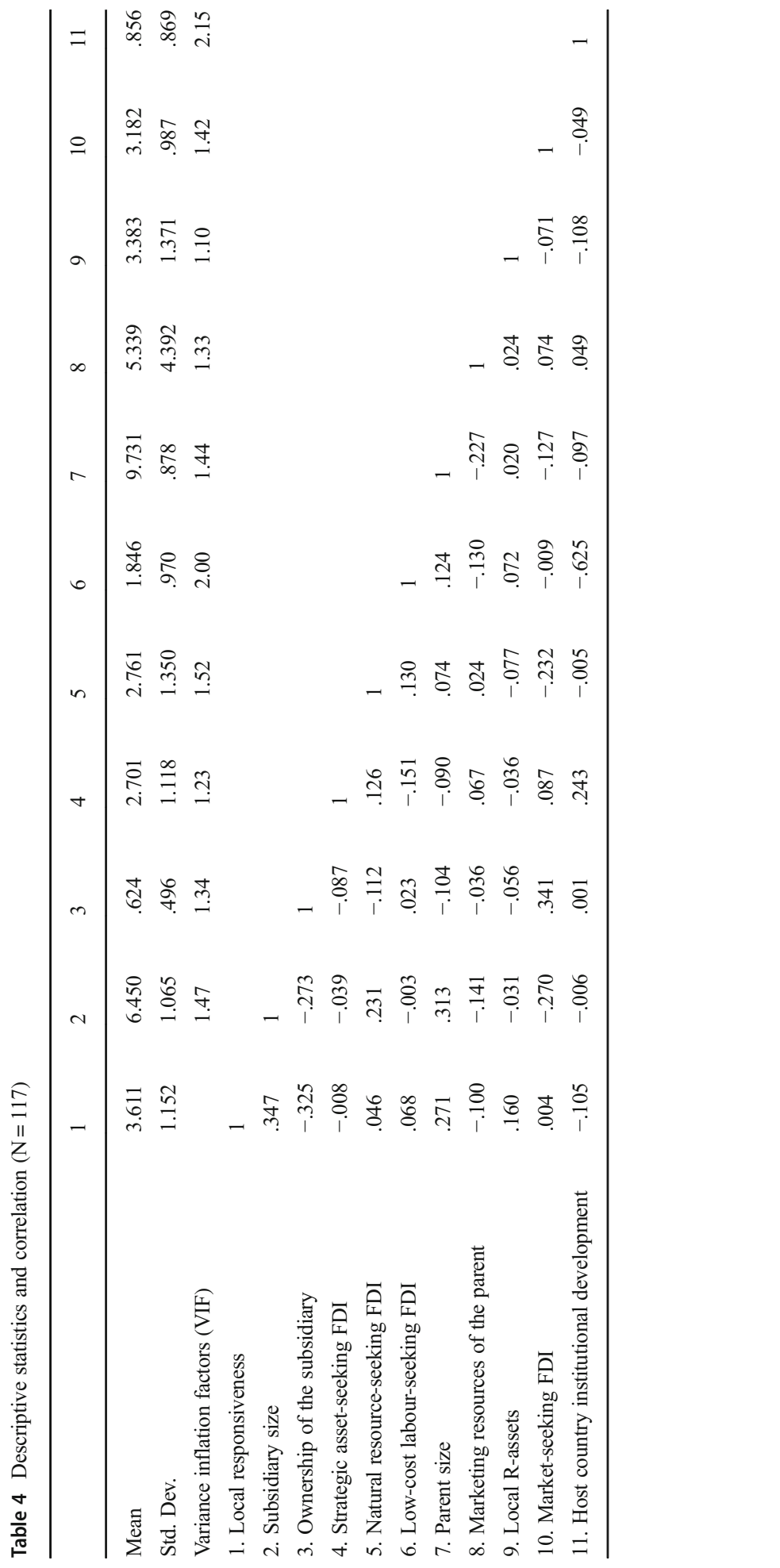


Table 5 OLS regression results $(\mathrm{N}=117)$

\begin{tabular}{llll}
\hline Variables & Model 1 & Model 2 & Model 3 \\
\hline Constant) & $.586(1.444)$ & $-.919(1.451)$ & $-1.466(1.561)$ \\
Subsidiary size & $.232^{*}(.112)$ & $.268^{*}(.268)$ & $.287^{* *}(.106)$ \\
Ownership of the subsidiary & $-.524^{*}(.224)$ & $-.645^{* *}(.222)$ & $-.582^{* *}(.221)$ \\
Strategic asset-seeking FDI & $.059(.096)$ & $.043(.092)$ & $.056(.092)$ \\
Natural resource-seeking FDI & $-.060(.089)$ & $-.026(.085)$ & $.005(.085)$ \\
Low-cost labour-seeking FDI & $.089(.109)$ & $.068(.136)$ & $.074(.135)$ \\
Parent size & $.172(.134)$ & $.136(.128)$ & $.096(.128)$ \\
Marketing resources of the parent & $-.010(.026)$ & $-.017(.025)$ & $-.024(.024)$ \\
Industry dummy included & & $.167 *(.072)$ & $.407 * *(.124)$ \\
H1: Local R-assets & & $.344 * *(.113)$ & $.310^{*}(.139)$ \\
H2: Market-seeking FDI & & $.012(.158)$ & $.697(.483)$ \\
H3: Host country institutional development & & & $-.231^{*}(.099)$ \\
H4: Local R-assets x host country institutional development & & $.039(.108)$ \\
H5: Market-seeking FDI x host country institutional development & & $2.98^{* * *}$ \\
F-value & $2.33 * *$ & $2.89 * * *$ & .2635 \\
Adjusted R ${ }^{2}$ & .1546 & .2366 & \\
\hline
\end{tabular}

$* * * \mathrm{p}<.001, * * \mathrm{p}<.01, * p<.05,{ }^{\circ} p<.1$

responsiveness strategy of foreign subsidiaries. One plausible explanation is that Chinese MNEs have developed a unique capability to operate successfully in uncertain economic and political environments similar to China (Buckley et al., 2008; Yiu et al., 2007). Foreign subsidiaries of Chinese MNEs face lower liabilities of foreignness and liabilities of origin when they expand to other developing countries because of their familiarity and experience in operating in institutional voids in the home country (Cuervo-Cazurra \& Genc, 2008; Cui \& Jiang, 2009; Hennart, 2012). As such, favourable conditions created by well-established institutions in achieving local responsiveness become less important in the case of foreign subsidiaries of Chinese MNEs.

Model 3 includes both independent variables and moderating effects. Hypothesis 4 is supported because the coefficient is .231 and the sign is negative $(p<.05)$, confirming that the level of institutional development of the host economy negatively moderates the impact of local R-assets on local responsiveness strategy. The finding suggests that local R-assets are more functional in weak and underdeveloped institutional contexts and they can be used to substitute for underdeveloped formal institutional infrastructures when the subsidiary implements a local responsiveness strategy.

In contrast, Hypothesis 5 is not supported because the coefficient estimate is insignificant. When we predict a positive moderating effect of host country institutional development on the relationship between market-seeking FDI and local responsiveness strategy, we highlight the necessity of local responsiveness strategy in order to achieve market seeking FDI because it facilitates the development of new technology and products for customers in advanced institutional countries. The insignificant result here may reflect the incapability of foreign subsidiaries of Chinese MNEs in tapping into 


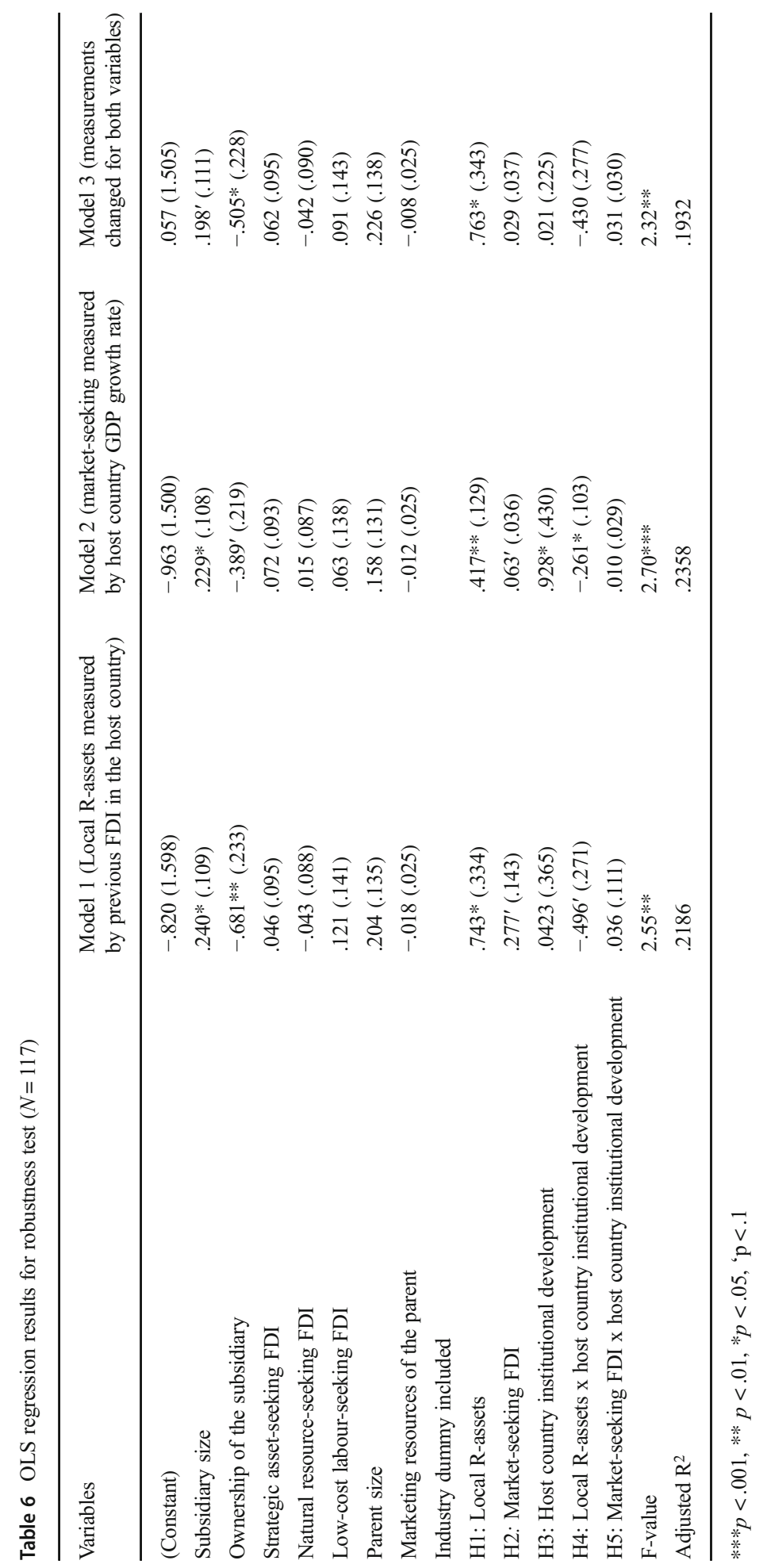


host country resources to increase local market share due to their lack of international experience in dealing with fierce competition in developed economies.

\section{Robustness tests}

We perform additional tests to check the robustness of our results. Specifically, we use alternative measurements for local R-assets and market-seeking FDI in which data are extracted from secondary data sources in replacement of survey data for these two variables reported in Table 5. This helps to exclude alternative explanations. First, it is argued that local network relationships (R-assets) are built by operating in local contexts and interacting with local stakeholders (Dunning, 2003; Peng, Wang, \& Jiang, 2008). As such, we measure R-assets by using a dummy variable which is assigned the value of 1 if the Chinese MNE has already established at least one subsidiary in the host country and 0 otherwise (Andersson, Arvidsson, \& Svensson, 1992; Andersson \& Svensson, 1994). Model 1 in Table 6 reports the results, which are consistent with findings reported earlier (Table 5), in which local R-assets are positively related with the local responsiveness strategy $(\mathrm{p}<.05)$ and its interaction with the host country institutional development is negative $(p<.1)$.

Second, we follow previous studies to use the GDP per capita and GDP growth rate as the alternative measurements of the market-seeking FDI (Buckley et al., 2007; Duanmu, 2012). We only report the results for the GDP growth rate because the host country institutional development is highly correlated with host country GDP per capita (.8675). Model 2 in Table 6 shows that the attractiveness of the local market is positively related to the local responsiveness strategy at a slightly significant level; and the moderator of the host country institutional development has no significant effect. These results are consistent with the findings in Table 5.

However, when we use secondary data for the measurements of both independent variables, only the local R-assets show the significant result $(\mathrm{p}<.05)$ in Model 3 of Table 6 . While the secondary data support our findings, the survey data shows stronger explanatory power in explaining the statistic model and thus provide stronger support for our hypotheses.

\section{Discussion}

\section{Contributions and implications}

Based on a sample of the foreign subsidiaries of Chinese MNEs, we examine the impacts of R-assets (a type of LB FSA for Chinese MNEs) and host CSAs of marketseeking FDI and host county institutional development on subsidiary-level local responsiveness strategy. The local responsiveness strategy is particularly important for foreign subsidiaries of Chinese MNEs because they are facing greater challenges in foreign markets due to their lack of existing Western-type FSAs (in offsetting the liabilities of foreignness) and the liabilities of origin as latecomer MNEs from emerging markets (Meyer et al., 2014; Wang et al., 2014). The local responsiveness strategy enables them to develop new resources, access to local complementary assets and establish local reputation, which help them overcome competitive disadvantages 
(Birkinshaw, 2014; Wei \& Nguyen, 2017). Our study reveals several new and important findings which enhance our understanding of the strategy of foreign subsidiaries of Chinese MNEs. Furthermore, it also provides novel and useful insights for theory development and managerial implications as outlined below.

First, we focus on subsidiary strategy by theorizing and providing new empirical evidence on the important role of local R-assets as a unique type of LB FSA which influences the local responsiveness strategy of foreign subsidiaries of Chinese MNEs. Previous studies document that Chinese MNEs and their subsidiaries possess R-assets which allow them to operate certain types of activities more effectively than local firms and advanced economy MNEs (Buckley et al., 2007; Wei, 2010; Yiu et al., 2007). We confirm this line of theoretical development by providing new empirical evidence that foreign subsidiaries of Chinese MNEs utilize the business practices of network relationships.

Second, our study explicitly examines and measures the extent to which host country CSAs of market-seeking FDI motivates foreign subsidiaries of Chinese MNEs to achieve a higher level of local responsiveness in host countries. This is a novel contribution given that previous studies in the extant literature on Chinese MNEs has largely focused on the strategic-asset seeking FDI as the 'springboard' to overcome the latecomer disadvantages (Li et al., 2012; Luo \& Tung, 2007) and has largely understated the role of market-seeking FDI. Thus, our study makes a novel contribution to the literature by conceptualizing and presenting new empirical evidence in which we show that market-seeking FDI enables foreign subsidiaries of Chinese MNEs to develop the local responsiveness strategy.

Third, our research finds that local R-assets and the level of host country institutional development have a negative synergistic effect on the local responsiveness strategy of foreign subsidiaries of Chinese MNEs. Our finding indicates that it is important to consider the host country environment in examining the effectiveness of R-assets for Chinese MNEs. Some scholars argue that Chinese MNEs can achieve rent-generating opportunities by exploiting R-assets in less-developed, emerging, and transitional economies (Cross et al., 2007; Cui \& Jiang, 2009). Our study confirms this perspective, in which the utilization of R-assets in achieving the local responsiveness strategy of the subsidiary is easier in countries with weak institutions because the network relationships act as a substitute for underdeveloped formal institutions, as well as with similar informal institutions, such as cultures and ideologies which are embedded in local environments.

However, it shows that possessing, utilizing and exploiting existing R-assets in a host country with relatively advanced institutional environment does not guarantee the successful local adaptation which is critical to overcome their post-entry disadvantages. In other words, foreign subsidiaries of Chinese MNEs can benefit little from the local knowledge pool and well-educated labour force in favourable institutional environment by exploiting existing R-assets of their parent firms. Our findings suggest that foreign subsidiaries of Chinese MNEs need to rely on other types of FSAs to enable them to compete in advanced institutions, such as learning experience in both domestic and host markets, inward FDI experience and absorptive capacity as documented in the literature (Buckley, Elia, \& Kafouros, 2014; Liu et al., 2016a, 2016b; Lyles, Li, \& Yan, 2014; Wu \& Voss, 2015).

The insignificant result of the moderating effect host country institutional development on the relationship between market-seeking FDI and local responsiveness strategy 
suggests that foreign subsidiaries of Chinese MNEs have limited international experience and managerial capabilities for market-seeking FDI in advanced economies and thus the benefits of local responsiveness strategy have not yet been accrued.

\section{Limitations and suggestions for future research}

Our study is subject to several limitations which may open new avenues for future research. First, the findings of our study are restricted to the 500 largest Chinese manufacturing MNEs which contribute to an increased likelihood of engaging in outward foreign direct investment activities. Future research may investigate the determinants of local responsiveness of subsidiaries of small and medium Chinese MNEs because their internationalization strategies may differ from large ones. Second, this study relies on a survey dataset. Data collection through a questionnaire survey is very challenging, especially the trend of declining response rates. Future research is suggested to use secondary data sources and objective measures. Third, the importance of local responsiveness strategy to Chinese MNEs' foreign success is restricted to theoretical discussions. Thus, another potential direction for future research is to examine how local responsiveness strategy enhances subsidiaries' competitiveness and increase their performance outcomes in global markets.

\section{Appendix: Extracted major constructs from the questionnaire}

Are you capable of understanding English?

questionnaire.' No; if no, please refer to the appropriate person or discard the

\section{Local responsiveness}

After foreign entry, the subsidiary responded actively to local environment, and adopted different products and customer service et al. for each of the following factor:

\begin{tabular}{llllllll}
\hline & not at all & average level & & & very much \\
\hline $\begin{array}{l}\text { local customer needs } \\
\text { local government policies } \\
\text { local market conditions } \\
\text { local rivalry situation }\end{array}$ & 1 & 2 & 3 & 4 & 5 & 6 & 7 \\
\hline
\end{tabular}

\section{Local relational assets (R-assets)}

At the time of entry, to what extent did you think the Chinese parent had established managerial or personal connections with local managers and officials at each of the following institutions? 


\begin{tabular}{|c|c|c|c|c|c|c|c|}
\hline & not at all & & rage & leve & & & very much \\
\hline & 1 & 2 & 3 & 4 & 5 & 6 & 7 \\
\hline \multicolumn{8}{|l|}{ buyers } \\
\hline \multicolumn{8}{|l|}{ suppliers } \\
\hline \multicolumn{8}{|l|}{ distributors } \\
\hline \multicolumn{8}{|l|}{ competitors } \\
\hline $\begin{array}{l}\text { officials in governments, industrial bureaus, tax bureaus, } \\
\text { banks and commercial administration et al. }\end{array}$ & & & & & & & \\
\hline
\end{tabular}

\section{FDI motives}

At the time of entry, to what extent was the subsidiary role related to the following statements?

\begin{tabular}{|c|c|c|c|c|c|}
\hline & not at all & & e level & & very much \\
\hline & 1 & 2 & 3 & 4 & 5 \\
\hline \multicolumn{6}{|l|}{ seek new markets in the host country } \\
\hline \multicolumn{6}{|c|}{$\begin{array}{l}\text { facilitate export to the host country (e.g., collect local } \\
\text { information, and respond to customer demands and } \\
\text { government requirements etc.) }\end{array}$} \\
\hline \multicolumn{6}{|l|}{ overcome trade barriers } \\
\hline \multicolumn{6}{|l|}{ seek advanced technology } \\
\hline \multicolumn{6}{|l|}{ obtain a well-known brand } \\
\hline \multicolumn{6}{|l|}{ gain management know-how } \\
\hline \multicolumn{6}{|l|}{ access to natural resources } \\
\hline \multicolumn{6}{|l|}{ access to low-cost labour } \\
\hline \multicolumn{6}{|l|}{ provide after-sale service } \\
\hline \multicolumn{6}{|l|}{ respond to Chinese government policy } \\
\hline others (Please specify) & & & & & \\
\hline
\end{tabular}

Open Access This article is distributed under the terms of the Creative Commons Attribution 4.0 International License (http://creativecommons.org/licenses/by/4.0/), which permits unrestricted use, distribution, and reproduction in any medium, provided you give appropriate credit to the original author(s) and the source, provide a link to the Creative Commons license, and indicate if changes were made.

\section{References}

Ahlstrom, D., \& Bruton, G. D. 2006. Venture capital in emerging economies: Networks and institutional change. Entrepreneurship Theory and Practice, 30(2): 299-320.

Andersson, T., Arvidsson, N., \& Svensson, R. 1992. Reconsidering the choice between takeover and greenfield operations, working paper 342. Stockholm:The Industrial Institute for Economic and Social Research. 
Andersson, T., \& Svensson, R. 1994. Entry modes for direct investment determined by the composition of firm-specific skill. Scandinavian Journal of Economics, 96(4): 551-560.

Bartlett, C. A., \& Ghosbal, S. 1989. Managing across borders: The transnational solution. Boston:Harvard Business School Press.

Bhaumik, S., \& Driffield, N. 2011. Direction of outward FDI of EMNEs: Evidence from the Indian pharmaceutical sector. Thunderbird International Business Review, 53(5): 615-628.

Birkinshaw, J. 1997. Entrepreneurship in multinational corporations: The characteristics of subsidiary initiative. Strategic Management Journal, 18(3): 207-229.

Birkinshaw, J. 2000. Entrepreneurship in the global firm. London:Sage.

Birkinshaw, J. 2014. Subsidiary initiative in the modern multinational corporation. In J. J. Boddewyn (Ed.). Multidisciplinary Insights from New AIB Fellows: (Research in Global Strategic Management, Volume 16): 201-220. Emerald Group Publishing Limited.

Birkinshaw, J., Hood, N., \& Young, S. 2005. Subsidiary entrepreneurship, internal and external competitive forces, and subsidiary performance. International Business Review, 14(2): 227-248.

Birkinshaw, J., Morrison, A. J., \& Hulland, J. 1995. Structural and competitive determinants of a global integration strategy. Strategic Management Journal, 16(8): 637-655.

Birkinshaw, J. M., \& Pedersen, T. 2009. Strategy and management in MNE subsidiaries. In A. M. Rugman (Ed.). The Oxford handbook of international business: 367-388. Oxford: Oxford University Press.

Bouquet, C., \& Birkinshaw, J. 2008. Weight versus voice: How foreign subsidiaries gain attention from corporate headquarters. Academy of Management Journal, 51(3): 577-601.

Brock, D. M., \& Birkinshaw, J. 2004. Multinational strategy and structure: A review and research agenda. Management International Review, 44(1): 5-14.

Brock, D. M., \& Hydle, K. M. 2018. Transnationality-sharpening the integration-responsiveness vision in global professional firms. European Management Journal, 36(1): 117-124.

Buckley, P., \& Casson, M. 1976. The future of the multinational enterprise. Basingstoke and London: Macmillan.

Buckley, P., Cross, A., Tan, H., Liu, X., \& Voss, H. 2008. Historic and emergent trends in Chinese outward direct investment. Management International Review, 48(6): 715-748.

Buckley, P. J., Clegg, J. L., Cross, A. R., Liu, X., Voss, H., \& Zheng, P. 2007. The determinants of Chinese outward foreign direct investment? Journal of International Business Studies, 38(4): 499-518.

Buckley, P. J., Elia, S., \& Kafouros, M. 2014. Acquisitions by emerging market multinationals: Implications for firm performance. Journal of World Business, 49(4): 611-632.

Cantwell, J. A., \& Mudambi, R. 2005. MNE competence-creating subsidiary mandates. Strategic Management Journal, 26(12): 1109-1128.

Chang, S. J., Witteloostuijn, A., \& Eden, L. 2010. From the editors: Common method variance in international business research? Journal of International Business Studies, 41(2): 178-184.

Cross, A., Buckley, P., Clegg, J., Voss, H., Rhodes, H., Zheng, P., \& Liu, X. 2007. An econometric investigation of Chinese outward direct investment. In J. H. Dunning, \& T. M. Lin (Eds.). Multinational enterprises and emerging challenge of the 21st century: 55-86. Cheltenham: Edward Elgar.

Cuervo-Cazurra, A., \& Genc, M. 2008. Transforming disadvantages into advantages: Developing country MNEs in the least developed countries. Journal of International Business Studies, 39(6): 957-979.

Cui, L., \& Jiang, F. 2009. FDI entry mode choice of Chinese firms: A strategic behaviour perspective. Journal of World Business, 44(4): $434-444$.

Cui, L., Meyer, K. E., \& Hu, H. W. 2014. What drives firms' intent to seek strategic assets by foreign direct investment? A study of emerging economy firms. Journal of World Business, 49(4): 488-501.

Deng, P. 2009. Why do Chinese firms tend to acquire strategic assets in international expansion? Journal of World Business, 44(1): 74-84.

Dikova, D., \& Witteloostuijn, A. V. 2007. Foreign direct investment mode choice: Entry and establishment modes in transition economies. Journal of International Business Studies, 38(6): 1013-1033.

Doz, Y. L., \& Prahalad, C. K. 1991. Managing MNCs: A search for a new paradigm. Strategic Management Journal, 12(1): 145-164.

Duanmu, J. L. 2012. Firm heterogeneity and location choice of Chinese multinational enterprises (MNEs). Journal of World Business, 47(1): 64-72.

Dunning, J. H. 1988. The eclectic paradigm of international production: A restatement and some possible extensions. Journal of International Business Studies, 19(1): 1-31.

Dunning, J. H. 1998. Location and the multinational enterprise: A neglected factor? Journal of International Business Studies, 29(1): 45-66.

Dunning, J. H. 2003. Relational assets, networks and international business activity. In J. H. Dunning, \& G. Boyd (Eds.). Alliance Capitalism and Corporate Management: 1-23. Edward Elgar Publishing Limited. 
Dunning, J. H. 2004. Relational assets: The new competitive advantages of MNEs and countries. In J. H. Dunning, \& R. Narula (Eds.). Multinationals and industrial competitiveness: 201-241. Cheltenham: Edward Elgar.

Dunning, J. H., \& Lundan, S. 2008. Multinational enterprises and the global economy, 2nd ed. Cheltenham: Edward Elgar.

Eden, L., \& Dai, L. 2010. Rethinking the O in Dunning's OLI paradigm. Multinational Business Review, 18(2): 13-34.

Eden, L., \& Miller, S. R. 2004. Distance matters: Liability of foreignness, institutional distance and ownership strategy. In M. Hitt, \& J. Cheng (Eds.). Advances in international management: 187-221. New York: Elsevier.

Engman, M., Onodera, O., \& Pinali, E. 2007. Export processing zones: Past and future role in trade and development. OECD Trade Committee (May).

Erdener, C., \& Shapiro, D. M. 2005. The internationalization of Chinese family enterprises and Dunning's eclectic MNE paradigm. Management and Organization Review, 1(3): 411-436.

Fornell, C., \& Larcker, D. F. 1981. Evaluating structural equation models with unobservable variables and measurement error. Journal of Marketing Research, 18(1): 39-50.

Giuliani, E., Gorgoni, S., Günther, C., \& Rabellotti, R. 2014. Emerging versus advanced country MNEs investing in Europe: A typology of subsidiary global-local connections. International Business Review, 23(4): 680-691.

Hair, J., Black, W. C., Babin, B. J., \& Anderson, R. E. 2010. Multivariate Data Analysis. In Pearson education international, upper saddle river. New: Jersey.

Haugland, S. A. 2010. The integration-responsiveness framework and subsidiary management: A commentary. Journal of Business Research, 63(1): 94-96.

He, X., Zhang, J., \& Wang, J. 2015. Market seeking orientation and performance in China: The impact of institutional environment, subsidiary ownership structure and experience. Management International Review, 55(3): 389-419.

Held, K., \& Berg, N. 2014. Facing discrimination by host country nationals emerging market multinational enterprises in developed markets. In Verbeke, A., Van Tulder, R., and Lundan, S. (Ed.), Multinational enterprises, markets and institutional diversity (Progress in International Business Research, Volume 9) (pp.417-441). Emerald Group Publishing Limited.

Hennart, J. F. 2009. Down with MNE-centric theories! Market entry and expansion as the bundling of MNE and local assets. Journal of International Business Studies, 40(9): 1432-1454.

Hennart, J. F. 2012. Emerging market multinationals and the theory of the multinational enterprise. Global Strategy Journal, 2(3): 168-187.

Hoskisson, R. E., Wright, M., Filatotchev, I., \& Peng, M. W. 2013. Emerging multinationals from mid-range economies: The influence of institutions and factor markets. Journal of Management Studies, 50(7): 1295-1321.

Hult, G. T. M., Ketchen, D. J., \& Slater, S. F. 2005. Market orientation and performance: An integration of disparate approaches. Strategic Management Journal, 20(12): 1157-1163.

Jiang, F. F., Wang, G., \& Jiang, X. 2018. Entrepreneurial orientation and organizational knowledge creation: A configurational approach. Asian Pacific Journal of Management. https://doi.org/10.1007/s10490-0189609-5.

Johansson, J. K., \& Yip, G. S. 1994. Exploiting globalization potential: U.S. and Japanese strategies. Strategic Management Journal, 15(88): 579-601.

Johnson, J. H. 1995. An empirical analysis of the integration-responsiveness framework: U.S. construction equipment industry firms in global competition. Journal of International Business Studies, 26(3): 621635.

Kang, Y., \& Jiang, F. 2012. FDI location choice of Chinese multinationals in east and Southeast Asia: Traditional economic factors and institutional perspective. Journal of World Business, 47(1): 45-53.

Khanna, T., \& Palepu, K. G. 2010. Winning in emerging markets: A roadmap for strategy and execution. Boston, MA:Harvard Business Press.

Kobrin, S. J. 1991. An empirical analysis of the determinants of global integration. Strategic Management Journal, 12(Special Issue): 17-31.

Kotabe, M., Jiang, C. X., \& Murray, J. Y. 2011. Managerial ties, knowledge acquisition, realized absorptive capacity and new product market performance of emerging multinational companies: A case of China. Journal of World Business, 46(2): 166-176.

Kwon, Y. C. 2010. Market orientation of Korean MNC subsidiaries and their performance in the Chinese and Indian markets. International Marketing Review, 27(2): 179-199. 
Li, H., \& Zhang, Y. 2007. The role of managers' political networking and functional experience in new venture performance: Evidence form China's transition economy. Strategic Management Journal, 28(8): 791804.

Li, J., Li, Y., \& Shapiro, D. 2012. Knowledge seeking and outward FDI of emerging market firms: The moderating effect of inward FDI. Global Strategy Journal, 2(4): 277-295.

Li, J. J., Zhou, K. Z., \& Shao, A. T. 2009. Competitive position, managerial ties, and profitability of foreign firms in China: An interactive perspective. Journal of International Business Studies, 40(2): 339-352.

Lin, S. L., \& Hsieh, A. T. 2010. International strategy implementation: Roles of subsidiaries, operational capabilities, and procedural justice. Journal of Business Research, 63(1): 52-60.

Lin, Z., Peng, M. W., Yang, H., \& Sun, S. L. 2009. How do networks and learning drive M\&as? An institutional comparison of China and the United States. Strategic Management Journal, 30(10): 1113-1132.

Liu, X., Gao, L., Lu, J., \& Lioliou, E. 2016a. Environmental risks, localization and the overseas subsidiary performance of MNEs from an emerging economy. Journal of World Business, 51(3): 356-368.

Liu, X., Gao, L., Lu, J., \& Lioliou, E. 2016b. Does learning at home and from abroad boost the foreign subsidiary performance of emerging economy multinational enterprises? International Business Review, 25(1): 141-151.

Lu, J., Liu, X., \& Wang, H. 2011. Motives for Chinese outward FDI: Firm resources, industry dynamics, and government policies. Management and Organization Review, 7(2): 223-248.

Lu, J., Liu, X., Wright, M., \& Filatotchev, I. 2014. The impact of domestic diversification and top management teams on international diversification of Chinese firms. International Business Review, 23(2): 455-467.

Luo, X., Griffith, D. A., Liu, S. S., \& Shi, Y. 2004. The effects of customer relationships and social capital on firm performance: A Chinese business illustration. Journal of International Marketing, 12(4): 25-45.

Luo, Y. 2001. Determinants of local responsiveness: Perspectives from foreign subsidiaries in an emerging market. Journal of Management, 27(4): 451-477.

Luo, Y. 2002. Organizational dynamics and global integration: A perspective from subsidiary managers. Journal of International Management, 8(2): 189-215.

Luo, Y. 2003. Market-seeking MNEs in an emerging market: How parent-subsidiary links shape overseas success. Journal of International Business Studies, 34(3): 290-309.

Luo, Y., Huang, Y., \& Wang, S. L. 2012. Guanxi and organizational performance: A meta-analysis. Management and Organization Review, 8(1): 139-172.

Luo, Y., Shenkar, O., \& Nyaw, M. K. 2002. Mitigating liabilities of foreignness: Defensive versus offensive liabilities approaches. Journal of International Management, 8(3): 283-300.

Luo, Y., \& Tung, R. L. 2007. International expansion of emerging market enterprises: A springboard perspective. Journal of International Business Studies, 38(4): 481-498.

Lyles, M., Li, D., \& Yan, H. 2014. Chinese outward FDI: The role of learning. Management and Organization Review, 10(3): 411-437.

Madhok, A., \& Keyhani, M. 2012. Acquisitions as entrepreneurship: Asymmetries op opportunities, and the internationalization of multinationals from emerging economies. Global Strategy Journal, 2(1): 26-40.

McMillan, J., \& Woodruff, C. 1999. Interfirm relationships and informal credit in Vietnam. Quarterly Journal of Economics., 114(4): 1285-1320.

Meyer, K. E. 2001. Institutions, transaction costs and entry mode choice in Eastern Europe. Journal of International Business Studies, 32(2): 357-367.

Meyer, K. E. 2015. What is "strategic asset seeking FDI"? The Multinational Business Review, 23(1): 57-66.

Meyer, K. E., Ding, Y., Li, J., \& Zhang, H. 2014. Overcoming distrust: How state-owned enterprises adapt their foreign entries to institutional pressures abroad. Journal of International Business Studies, 45(8): 1005-1028.

Meyer, K. E., \& Estrin, S. 2014. Local context and global strategy: Extending the integration responsiveness framework to subsidiary strategy. Global Strategy Journal, 4(1): 1-19.

Meyer, K. E., Estrin, S., Bhaumik, S., \& Peng, M. W. 2009. Institutions, resources and entry strategies in emerging economies. Strategic Management Journal, 30(1): 61-80.

Meyer, K. E., Mudambi, R., \& Narula, R. 2011. Multinational enterprises and local con- texts: The opportunities and challenges of multiple embeddedness? Journal of Management Studies, 48(2): 235-252.

Meyer, K. E., \& Nguyen, H. V. 2005. Foreign investment strategies and sub-national institutions in emerging markets: Evidence from Vietnam. Journal of Management Studies, 42(1): 63-93.

Meyer, K. E., \& Su, Y. S. 2015. Integration and responsiveness in subsidiaries in emerging economies. Journal of World Business, 50(1): 149-158.

Morrison, A. J., \& Roth, K. 1992. A taxonomy of business-level strategies in global industries. Strategic Management Journal, 13(6): 399-417. 
Narula, R., \& Santangelo, G. D. 2012. Location and collocation advantages in international innovation. Multinational Business Review, 20(1): 6-25.

Nguyen, Q. T. K., \& Almodóvar, P. 2018. Export intensity of foreign subsidiaries of multinational enterprises: The role of trade finance availability. International Business review, 27(1): 231-245.

Nguyen, Q. T. K., \& Rugman, A. M. 2015a. Internal equity financing and the performance of multinational subsidiaries in emerging economies. Journal of International Business Studies, 46(4): 468-490.

Nguyen, Q. T. K., \& Rugman, A. M. 2015b. Multinational subsidiary sales and performance in South East Asia. International Business Review, 24(1): 115-123.

North, D. C. 1990. Institutions, institutional change, and economic performance. Cambridge, MA:Harvard University Press.

Park, S. H., \& Luo, Y. 2001. Guanxi and organizational dynamics: Organizational networking in Chinese firms. Strategic Management Journal, 22(5): 455-477.

Peng, M. 2014. Global strategic management, 3rd ed. Cengage:South-Western.

Peng, M. W. 2003. Institutional transitions and strategic choices. Academy of Management Review, 28(2): 275-296.

Peng, M. W. 2012. The global strategy of emerging multinationals from China. Global Strategy Journal, 2(2): 97-107.

Peng, M. W., \& Luo, Y. 2000. Managerial ties and firm performance in a transition economy: The nature of a micro-macro link. Academy of Management Journal, 43(3): 486-501.

Peng, M. W., Wang, D., \& Jiang, Y. 2008. An institution-based view of international business strategy: A focus on emerging economies. Journal of International Business Studies, 39(5): 920-936.

Porter, M. E. 1986. Competition in global industries: A conceptual framework. In M. E. Porter (Ed.). Competition in global industries: 15-60. Boston: Harvard Business School Press.

Prahalad, C. K., \& Doz, Y. L. 1987. The multinational mission: Balancing local demands and global vision. New York:The Free Press.

Puffer, S., \& McCarthy, D. 2011. Two decades of Russian business and management research: An institutional theory perspective. Academy of Management Perspectives., 25(2): 21-36.

Ramachandran, J., \& Pant, A. 2010. The liabilities of origin: An emerging economy perspective on the costs of doing business abroad. In D. Timothy., Torben, P., and Laszlo, T. (Eds.), The past, present and future of international business and management, advances in international management (pp. 231-265). Emerald Group Publishing.

Ramamurti, R. 2009. What have we learned about emerging market MNEs? In R. Ramamurti, \& J. Singh (Eds.). Emerging multinationals in emerging markets: 399-426. Cambridge, U.K.: Cambridge University Press.

Ramamurti, R. 2012. What is really different about emerging market multinationals? Global Strategy Journal, 2(1): $41-47$.

Rao, R. S., Chandy, R. K., \& Prabhu, J. C. 2008. The fruits of legitimacy: Why some new ventures gain more from innovation than others. Journal of Marketing, 72(4): 58-75.

Roll, M. 2014. How nations and brands overcome country of origin challenges. [Cited 07 September 2017.] Available from URL: http://www.martinroll.com/resources/articles/marketing/how-nations-and-brandsovercome-country-of-origin-challenges/. Accessed 25 Mar 2019.

Roth, K., David, M. S., \& Morrisson, A. J. 1991. Global strategy implementation at the business unit leveloperational capabilities and administrative mechanisms. Journal of International Business Studies, 22(3): 369-402.

Roth, K., \& Morrison, A. J. 1990. An empirical analysis of the integration-responsiveness framework in global industries. Journal of International Business Studies, 21(4): 541-564.

Rugman, A. M. 1981. Inside the multinationals: The economics of internal markets. New York: Columbia Press. Reissued by Palgrave Macmillan in 2006 as Inside the Multinationals, (25th Anniversary Edition), Basingstoke and New York: Palgrave Macmillan.

Rugman, A. M. 2010. Reconciling internalization theory and the eclectic paradigm. Multinational Business Review, 18(2): 1-12.

Rugman, A. M., \& Li, J. 2007. Will China's multinationals succeed globally or regionally? European Management Journal, 25(5): 333-343.

Rugman, A. M., Nguyen, Q. T. K., \& Wei, Z. Y. 2014. Chinese multinationals and public policy. International Journal of Emerging Market, 9(2): 205-215.

Rugman, A. M., Nguyen, Q. T. K., \& Wei, Z. Y. 2016. Rethinking the literature on the performance of Chinese multinational enterprises. Management and Organization Review, 12(2): 269-302.

Rugman, A. M., \& Verbeke, A. 1992. A note on the transnational solution and the transaction cost theory of multinational strategic management. Journal of International Business Studies, 23(4): 761-771. 
Rugman, A. M., \& Verbeke, A. 2001. Subsidiary-specific advantages in multinational enterprises. Strategic Management Journal, 22(3): 237-250.

Rugman, A. M., \& Verbeke, A. 2003. Extending the theory of the multinational enterprise: Internalization and strategic management perspectives. Journal of International Business Studies, 34(2): 125-137.

Rugman, A. M., \& Verbeke, A. 2008. Internalization theory and its impact on the field of international business. In Boddewyn, J.J. (Ed.), International business scholarship: AIB fellows on the first 50 years and beyond (research in global strategic management): 155-174. Emerald Group Publishing Limited.

Rugman, A. M., Verbeke, A., \& Quyen, T. K. N. 2011a. Fifty years of international business theory and beyond. Management International Review, 51(6): 755-786.

Rugman, A. M., Verbeke, A., \& Yuan, W. 2011b. Re-conceptualizing Bartlett and Ghoshal's classification of national subsidiary roles in the multinational enterprise. Journal of Management Studies, 48(2): 253-277.

Scott, W. R. 1995. Institutions and organizations. Thousand Oaks, CA:Sage.

Sheng, S., Zhou, K. Z., \& Li, J. J. 2011. The effects of business and political ties on firm performance: Evidence from China. Journal of Marketing, 75(1): 1-15.

Sun, S. L., Peng, M. W., Ren, B., \& Yan, D. 2012. A comparative ownership advantage framework for crossborder M\&As: The rise of Chinese and Indian MNEs. Journal of World Business, 47(1): 4-16.

Taggart, J. H. 1998. Strategy shifts in MNC subsidiaries. Strategic Management Journal, 17(1): 663-681.

Tallman, S., \& Yip, G. 2009. Strategy and the multinational enterprise. In A. M. Rugman (Ed.). The Oxford handbook of international business: 307-340. New York: Oxford University Press.

Tseng, C. H., \& Chang, Y. W. 2005. The effects of MNC subsidiary's integration and local responsiveness on its performance: An empirical study of Taiwanese enterprises' subsidiaries. International Journal of Business Performance, 7(4): 409-420.

Verbeke, A. 2013. International business strategy: Rethinking the foundations of global corporate success, 2nd ed. Cambridge University Press.

Wang, C. Q., Hong, J. J., Kafouros, M., \& Wright, M. 2012. Exploring the role of government involvement in outward FDI from emerging economies? Journal of International Business Studies, 43(7): 655-676.

Wang, S. L., Luo, Y., Lu, X., Sun, J., \& Maksimov, V. 2014. Autonomy delegation to foreign subsidiaries: An enabling mechanism for emerging market multinationals? Journal of International Business Studies, 45(2): 111-130.

Wang, Y. L., \& Shao, Y. M. 2016. Motivations of Chinese outward direct investment: The sector perspective. Journal of Systems Science and Complexity, 29(3): 698-721.

Wei, Z. Y. 2010. The literature on Chinese outward FDI. Multinational Business Review, 18(3): 73-112.

Wei, Z. Y., \& Nguyen, Q. T. K. 2017. Subsidiary strategy of emerging market multinationals: A home country institutional perspective. International Business Review, 26(5): 1009-1021.

Williams, C., Colovic, A., \& Zhu, J. 2017. Integration-responsiveness, local hires and subsidiary performance amidst turbulence: Insights from a survey of Chinese subsidiaries. Journal of World Business, 52(6): 842-853.

Witt, M. A., \& Lewin, A. Y. 2007. Outward foreign direct investment as escape response to home country institutional constraints. Journal of International Business Studies, 38(4): 579-594.

Wu, A., \& Voss, H. 2015. When does absorptive capacity matter for international performance of firms? Evidence from China. International Business Review, 24(2): 344-351.

Xin, K. R., \& Pearce, J. L. 1996. Guanxi: Connections as substitutes for formal institutional support. The Academy of Management Journal, 39(6): 1641-1658.

$\mathrm{Xu}, \mathrm{D} .$, \& Shenkar, O. 2002. Institutional distance and the multinational enterprise. The Academy of Management Review, 27(4): 608-618.

Yip, G. S. 1995. Total global strategy. Englewood Cliffs, NJ:Prentice Hall.

Yiu, D. W., Lau, C., \& Bruton, G. D. 2007. International venturing by emerging economy firms: The effects of firm capabilities, home country networks, and corporate entrepreneurship. Journal of International Business Studies, 4(38): 519-540.

Zhang, J., \& Keh, H. T. 2010. Interorganizational exchanges in China: Organizational forms and governance mechanisms. Management and Organization Review, 6(1): 123-147.

Zhou, K. Z., Poppo, L., \& Yang, Z. 2008. Relational ties or customized contracts? An examination of alternative governance choices in China. Journal of International Business Studies, 39(3): 526-534.

Publisher's note Springer Nature remains neutral with regard to jurisdictional claims in published maps and institutional affiliations. 
Dr. Ziyi Wei is a Lecturer of Chinese Studies at School of East Asia Studies, University of Sheffield, the United Kingdom. She earned her Ph.D. degree in international business and strategy from Henley Business School, University of Reading, the United Kingdom. Her research focuses on outward foreign direct investment of Chinese firms, internationalization strategies of emerging economy multinational enterprises (EMNEs), internationalization and performance of EMNEs, headquarters-subsidiary relationships, and subsidiary strategy of EMNEs.

Quyen T.K. Nguyen is an Associate Professor of International Business and Strategy at Henley Business School, University of Reading, the United Kingdom. She earned her Ph.D. degree in international business and strategy from Henley Business School, University of Reading, the United Kingdom. Her research focuses on multinational subsidiary strategy and performance, assessing foreign subsidiary performance, parentsubsidiary relationship in financial management, inter-disciplinary research of integrating international business with international financial management. 